\title{
Zastosowanie widm wyższych rzędów do analizy sygnałów napięcia spawania
}

\author{
Application of wavelet transform \\ to analysis of welding voltage signals
}

\section{Streszczenie}

W artykule zaprezentowano wyniki badań nad zastosowaniem widma trzeciego rzędu do analizy sygnałów napięcia spawania. Widma wyższych rzędów w przeciwieństwie do powszechnie stosowanego widma mocy sygnału zachowują informację o zależnościach fazowych i pozwalają w pełni scharakteryzować niestabilności procesu spawania, co potwierdzają przeprowadzone badania.

Słowa kluczowe: MAG; monitorowanie spawania; analiza widmowa wyższych rzędów

\begin{abstract}
The article presents results of research on the application of third-order spectrum to analysis of the welding voltage signals. Higer-order spectra in contrast to the commonly used power spectrum carry information phase and allow to fully characterize the instability of the welding process which is confirmed by studies carried out.
\end{abstract}

Keywords: GMA; welding monitoring; higher order spectral analysis

\section{Wstęp}

Trwająca czwarta rewolucja przemysłowa nazywana również Przemysłem 4.0, stawia ambitne wyzwania przedsiębiorstwom pod kątem automatyzacji i kontroli jakości produkcji. Wyzwania te odnoszą się również do przemysłowego wykorzystania technologii spawalniczych. Automatyzacja procesu spawania i bieżąca kontrola jakości złącza wymaga stosowania układów ciągłego monitorowania i kontroli sygnałów generowanych w trakcie wykonywania złącza i będących jednocześnie nośnikiem informacji o stanie procesu spawania. Mowa tutaj o sygnałach procesowych takich jak natężenie prądu, napięcie łuku, natężenie przepływu gazu, prędkość podawania drutu; sygnałach resztkowych (dźwięk, drgania, temperatura); promieniowaniu elektromagnetycznym itp. [3]. Skuteczna detekcja i identyfikacja niezgodności procesu spawania wymaga odpowiedniego przetwarzania i analizy sygnałów procesowych. Istnieją różne metody pozwalające oceniać sygnały procesowe [2]. Wykorzystują one parametry statystyczne, różnorodne przekształcenia przestrzeni wartości sygnałów (np. Transformata Fouriera, PCA) itp. Należy jednak zauważyć, że analiza sygnałów spawania nie jest zadaniem prostym ze względu na ich dynamiczny i niestacjonarny charakter oraz duży udział składowych losowych. Przykładem sygnału spawania o złożonej strukturze zarówno w dziedzinie amplitud, jak i czasu jest sygnał napięcia spawania.
W artykule przedstawiono przykład wykorzystania, znanych od dawna [6], ale bardzo rzadko stosowanych w analizie sygnałów spawania, statystyk i widm wyższych rzędów.

\section{Analiza widmowa wyższych rzędow}

W analizie sygnałów generowanych podczas spawania powszechnie wykorzystywane są miary sygnałów bazujące na momentach drugiego rzędu, mowa tutaj głównie o funkcji korelacji, widmie mocy sygnału i ocenach liczbowych jak wartość średnia, średniokwadratowa itp. Analiza sygnałów oparta na funkcji korelacji, widmie mocy sygnatu czy rozkładach czasowo-częstotliwościowych posiada pewne ograniczenia w zakresie możliwości badania i opisu związków fazowych zachodzących między składowymi sygnału wynikających ze specyficznych zjawisk opisywanych przez sygnał $[1,4,5]$. Uogólnieniem momentów drugiego rzędu są momenty wyższych rzędów i ich szczególne kombinacje nieliniowe zwane kumulantami. Ogólnie kumulanta n-tego rzędu jest definiowana jako różnica między n-tym momentem sygnału $x(t)$ i $n$-tym momentem równoważnego mu stacjonarnego sygnału o rozkładzie normalnym, co pozwala stwierdzić, że kumulanta przyjmuje wartości zerowe dla sygnałów o rozkładzie normalnym [1]. Dla sygnału

Dr hab. inż. Marek Fidali - Politechnika Śląska.

Autor korespondencyjny/Corresponding author: marek.fidali@polsl.pl 
stacjonarnego $\mathrm{x}(\mathrm{t})$ o wartościach rzeczywistych i zerowej wartości średniej $E\{x(t)\}=0$ kumulanty pierwszego, drugiego, trzeciego i czwartego rzędu zdefiniowane są następująco [1,5]:

$$
\begin{aligned}
& C_{1 x}=E\{x(t)\}=0 \\
& C_{2 x}(k)=E\{x(t) x(t+k)\}, \\
& C_{3 x}(k, l)=E\{x(t) x(t+k) x(t+l)\} \\
& \begin{aligned}
C_{4 x}(k, l, m)= & E\{x(t) x(t+k) x(t+l) x(t+m)\}-C_{2 x}(k) C_{2 x}(l-m)- \\
& \quad-C_{2 x}(l) C_{2 x}(k-m)-C_{2 x}(m) C_{2 x}(k-l),
\end{aligned}
\end{aligned}
$$

Kumulanta pierwszego rzędu jest równa wartości oczekiwanej sygnału, kumulanta drugiego rzędu to kowariancja. Dla zerowych przesunięć czasowych kumulanty stają się parametrami liczbowymi opisującymi sygnał, takimi jak: wariancja $\mathrm{C}_{2 x}(0)=\sigma_{x}{ }^{2}$, asymetria $\mathrm{C}_{3 x}(0,0) / \sigma_{x}{ }^{3}$ i kurtoza $\mathrm{C}_{4 x}(0,0,0) / \sigma_{x}{ }^{4}$.

Zastosowanie transformaty Fouriera wobec kumulant pozwala na wyznaczenie widm wyższych rzędów, a mianowicie widma mocy sygnału $S_{2 x}(f)(5)$, bispektrum $S_{3 x}(6)$ i trispektrum $S_{4 x}\left(f_{1}, f_{2}, f_{3}\right)(7)$ w następujący sposób $[1,5]$ :

$S_{2 x}(f)=\sum_{k=-\infty}^{\infty} C_{2 x}(k) e^{-j 2 \pi f k}$,

$S_{3 x}\left(f_{1}, f_{2}\right)=\sum_{k=-\infty}^{\infty} \sum_{l=-\infty}^{\infty} C_{3 x}(k, l) e^{-j 2 \pi f\left(f_{1} k+f_{2} l\right)}$,

$S_{4 x}\left(f_{1}, f_{2}, f_{3}\right)=\sum_{k=-\infty}^{\infty} \sum_{l=-\infty}^{\infty} \sum_{m=-\infty}^{\infty} C_{4 x}(k, l, m) e^{-j 2 \pi f\left(f_{1} k+f_{2} l+f_{3} m\right)}$,

Zastosowanie analiz bazujących na kumulantach wyższych rzędów i ich widmach umożliwia badanie statystycznych zależności pomiędzy składowymi częstotliwościowymi sygnału, wykrywanie i identyfikację składowych powstałych w wyniku występowania zjawisk nieliniowych oraz dodatkowych sprzężeń zwrotnych, a także redukcję szumów w sygnałach.

Metody te są szczególnie skuteczne tam, gdzie mamy do czynienia z procesami losowymi nieposiadającymi rozkładu normalnego.

W artykule ograniczono się do prezentacji wyników stosowania analizy widmowej trzeciego rzędu w oparciu o bispektrum. Bispektrum jest ilościową miarą sprzężenia pomiędzy składowymi częstotliwościowymi, wyznaczoną na płaszczyźnie o odpowiednich współrzędnych częstotliwościowych nazywanych biczęstotliwościami [5]. Duża wartość bispektrum dla określonych par częstotliwości (i kombinacji ich sum lub różnic) wskazuje na istnienie sprzężenia częstotliwościowego pomiędzy nimi. Może to oznaczać, że rozważane składowe częstotliwościowe mają wspólny generator, co w obecności nieliniowości wyższych rzędów układu może prowadzić do syntetyzowania wspólnych nowych składowych częstotliwościowych. Jednym z powodów wystąpienia zjawisk nieliniowych jest kwadratowe sprzężenie fazy (Quadratic Phase Coupling). Bispektrum dodatkowo opisuje skośność funkcji gęstości rozkładu prawdopodobieństwa [4,5].

Normalizacja bispektrum pozwala zdefiniować miarę przyjmującą wartości z przedziału od 0 do 1 a nazywaną bikoherencją [5]:

$$
b\left(f_{1}, f_{2}\right)=\frac{S_{3 x}\left(f_{1}, f_{2}\right)}{\sqrt{S_{2 x}\left(f_{1}\right) S_{2 x}\left(f_{2}\right) S_{2 x}\left(f_{1}+f_{2}\right)}}
$$

Bispektrum podobnie jak widmo mocy sygnału ma własności symetrii na płaszczyźnie $\left(\mathrm{f}_{1}, \mathrm{f}_{2}\right)$, co pozwala na ograniczenie obliczeń i prezentację wartości w obszarze nieredundantnym w postaci wykresów trójwymiarowych lub map. Ze względu na własności symetrii można wskazać obszar nieredundantny nazywany dziedziną główną (rys.1) zdefiniowany przez trójkąt o wierzchołkach $(0,0),\left(\left(\mathrm{f}_{\mathrm{s}} / 3, \mathrm{f}_{\mathrm{s}} / 3\right)\right)$ $\mathrm{i}\left(\mathrm{f}_{\mathrm{s}} / 2,0\right)$, gdzie $\mathrm{f}_{\mathrm{s}}$ jest częstotliwością próbkowania [5].

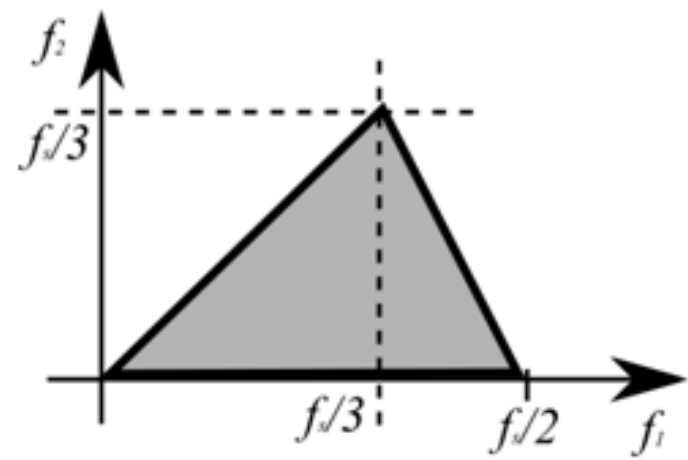

Rys. 1. Nieredundantny obszar wartości bispektrum przedstawiający dziedzinę główną

Fig. 1. The non-redundant part of the bispectral plane, showing the principal domain

W przypadku analizy sygnału procesu spawania, w którym mogą pojawić się niestabilności, celowa jest segmentacja realizacji sygnału na, krótsze podrealizacje, z których wyznaczane mogą być statystyki widma wyższych rzędów. Ponieważ wartości widm wyższych rzędów są zdefiniowane przez wielowymiarowe macierze wartości, konieczne jest określenie parametru liczbowego, opisującego całkowitą moc sygnału w dziedzinie głównej. Dla potrzeb niniejszych badań zdefiniowano parametr będący sumą wartości kwadratowych wyliczanych ze znormalizowanych wartości widma wyższego rzędu. W przypadku bikoherencji można go zdefiniować następująco:

$$
S=\sum\left|b\left(f_{1}, f_{2}\right)\right|^{2}
$$

gdzie $b\left(f_{1}, f_{2}\right)$ jest funkcją bikoherencji. W przypadku, gdy sygnał będzie sygnałem losowym o rozkładzie Gaussa, należy się spodziewać, że wartości bikoherencji będą wynosiły 0 , a zatem i parametr $S$ będzie równy zero lub będzie miał wartość bardzo niską. W przypadku silnych nieliniowości w bispektrum pojawią się intensywne składowe co wpłynie również na znaczący wzrost wartości parametru S.

\section{Analizowane sygnały}

Dla potrzeb analiz z zastosowaniem widm wyższych rzędów wykorzystano rzeczywiste sygnały napięcia zarejestrowane $w$ trakcie spawania odpowiednio przygotowanych próbek wykonanych z prostokątnych blach ze stali S235JR (EN 10027-1) o rozmiarach 300 x 150 × 5 mm. Do spawania wykorzystano zmechanizowane stanowisko do prostoliniowego spawania metodą MIG/MAG (rys. 2). Jako materiał dodatkowy stosowano drut elektrodowy lity o średnicy 1,2 mm. Osłonę gazową stanowiła mieszanka M21 (82\%Ar + 18\% $\left.\mathrm{CO}_{2}\right)$. Nominalne parametry spawania zaprezentowano $\mathrm{w}$ tablicy 1 .

Tablica I. Nominalne parametry spawania łukowego metodą MAG Table I. Nominal parameters of GMA arc welding

\begin{tabular}{|l|c|}
\hline Prąd Spawania [A] & 240 \\
\hline Napięcie spawania [V] & 25 \\
\hline Prędkość spawania [cm/min] & 32 \\
\hline Prędkość podawania drutu [m/min] & 7,4 \\
\hline Natężenie przepływu gazu osłonowego [1/min] & 15 \\
\hline Wystający odcinek elektrody [mm] & 15 \\
\hline
\end{tabular}




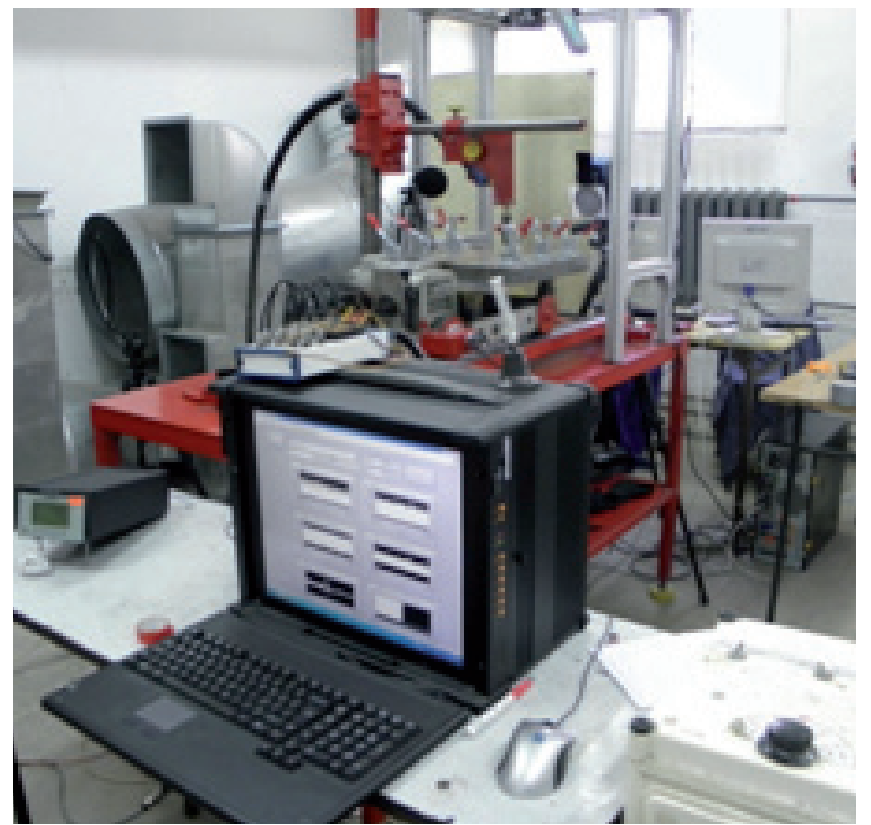

Rys. 2. Widok stanowiska badawczego

Fig. 2. View of the test bench

Na stanowisku badawczym przeprowadzono szereg eksperymentów w trakcie, których symulowano różne nieprawidłowości procesu spawania wpływając tym samym na cechy jakościowe złącza spawanego. Symulowano takie stany procesu spawania jak:

S1 - spawanie bez zakłóceń;

S2 - spawanie, w trakcie którego nastąpił zanik przepływu gazu osłonowego;

S3 - spawanie blach z nieprawidłowym przygotowaniem krawędzi od strony grani (otwory);

S4 - spawanie blach z zabrudzeniami olejowymi na łączonych powierzchniach;

S5 - spawanie, podczas którego następowały zmiany wartości prądu;

S6 - spawanie w trakcie którego dokonywano zmian napięcia spawania;

S7 - spawanie blach o nierównoległych (rozszerzających się) krawędziach.

Eksperymenty przeprowadzono $\mathrm{w}$ ramach projektu badawczego nr N504 281937 pt. Metodologia diagnozowania procesu spawania z wykorzystaniem fuzji obrazów realizowanego w Instytucie Podstaw Konstrukcji Maszyn przy współpracy z pracownikami Katedry Spawalnictwa, Politechniki Śląskiej.

$\mathrm{Na}$ rysunku 3 przedstawiono widok połączenia spawanego od strony lica i grani uzyskanego podczas spawania, w trakcie którego wystąpił dwukrotny zanik przepływu gazu osłonowego.

\section{Wyniki badań}

Sygnały napięcia zarejestrowane podczas spawania poddano analizie wykorzystując widma wyższy rzędów. Ze względu na ograniczenia objętościowe, w artykule przedstawiono wyniki analizy sygnału zarejestrowanego dla stanu S2, czyli procesu spawania blach, w trakcie którego nastąpił dwukrotny chwilowy zanik przepływu gazu osłonowego. Przebieg zarejestrowanego sygnału zaprezentowano na rysunku 4 . W sygnale widoczne są wyraźnie zmiany wartości amplitudy w chwili wystąpienia niestabilności. Próbki sygnału zbierano z częstotliwością 10 kHz.

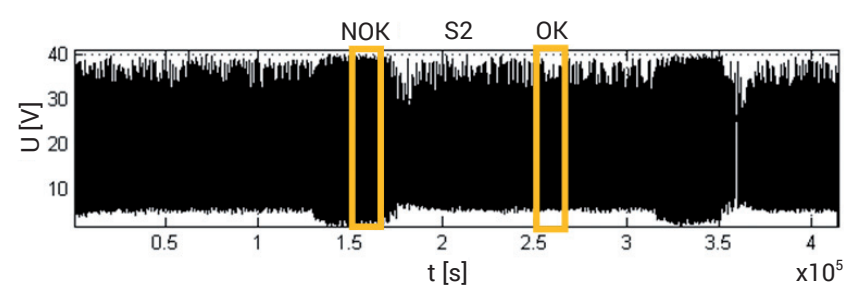

Rys. 4. Przebieg sygnału napięcia zarejestrowany podczas spawania z chwilowym zanikiem osłony gazowej

Fig. 4. Signal of voltage acquired during welding with the temporary loss of shielding gas flow

W celu wyznaczenia widma wyższego rzędu - bispektrum, z zarejestrowanego sygnału napięcia wybrano dwie podrealizacje sygnału reprezentujące proces prawidłowy (OK) i nieprawidłowy (NOK). Fragmenty brane do analizy zaznaczono na rysunku 4. Każda podrealizacja miała długość 1,64 s. Na rysunku 5 przestawiono bispektra, odpowiednio dla sygnału opisującego proces prawidłowy (rys. 5a) i nieprawidłowy (rys. 5b). Widoczne są wyraźne różnice $w$ rozkładzie składowych częstotliwościowych bispektum.
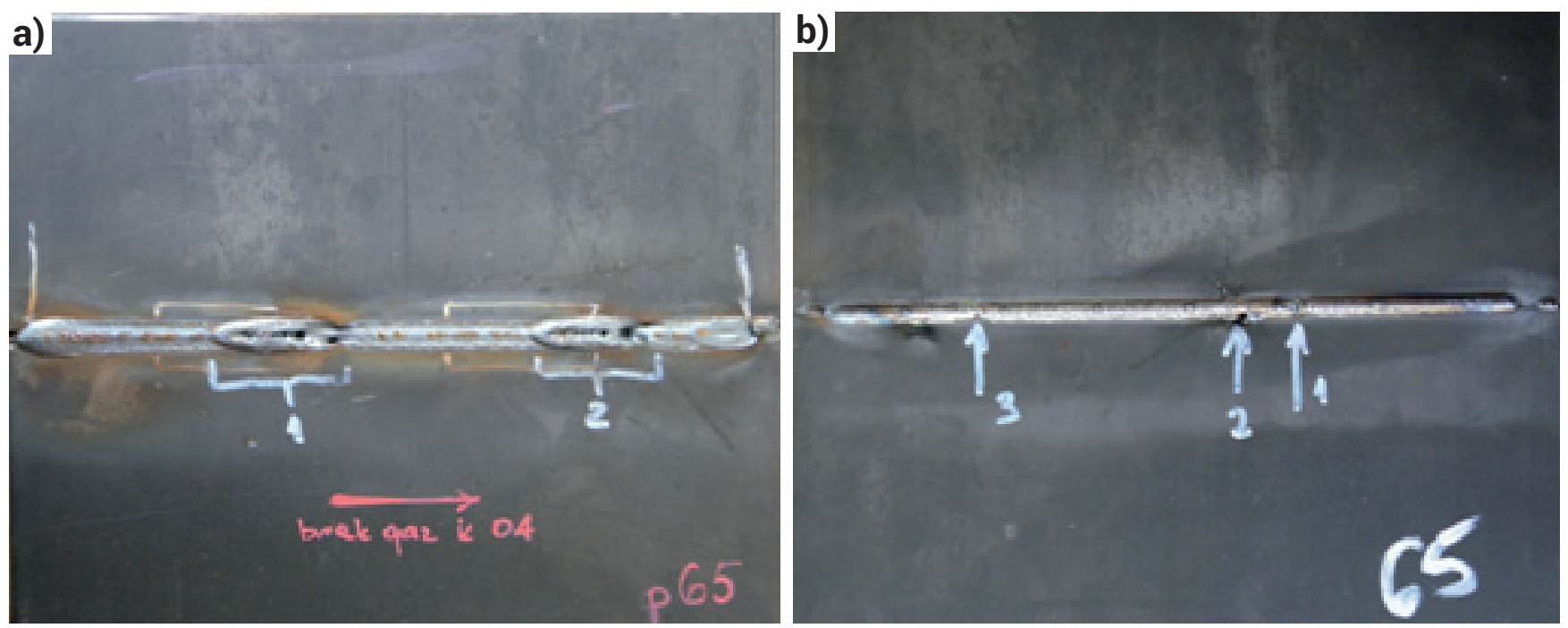

Rys. 3. Widok złącza spawanego od strony lica a) i grani b) uzyskanego podczas spawania z chwilowym zanikiem osłony gazowej Fig. 3. View of the welded joint on the face $a$ ) and root b) side obtained during welding with the momentary loss of shielding gas flow 

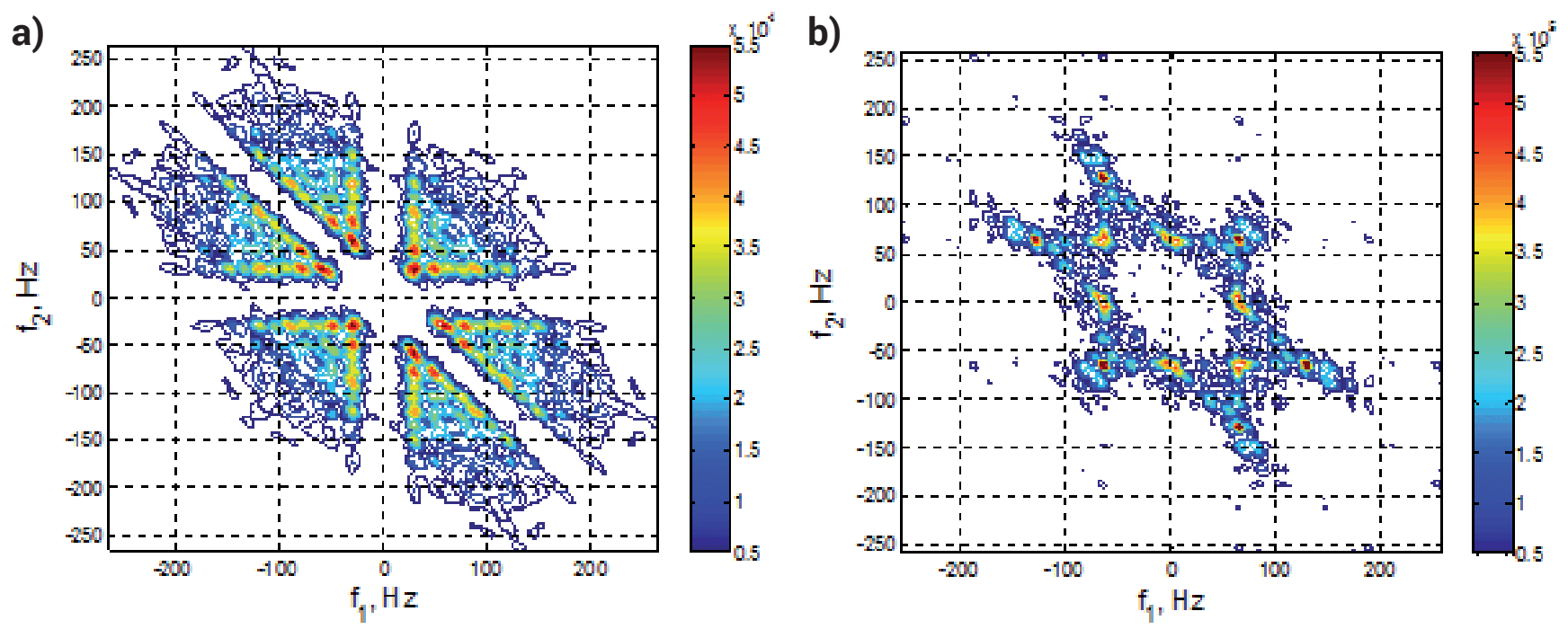

Rys. 5. Bispektra sygnału napięcia zarejestrowanego podczas spawania: a) bez zakłóceń b) z chwilowym zanikiem osłony gazowej Fig. 5. Biscpectra of voltage signal acquired during welding: a) without disturbances b) with the temporary loss of shielding gas flow

Na rysunkach widoczne są obszary symetryczne, zatem aby dokładniej zbadać strukturę częstotliwościową sygnałów skoncentrowano się na pierwszych ćwiartkach wykresu a dokładniej na obszarze nieredundantym omówionym w rozdziale 2 artykułu. Na rysunku 6 zaprezentowano w postaci wykresów konturowych i trójwymiarowych widok pierwszej ćwiartki bispektrów widocznych na rysunku 5.
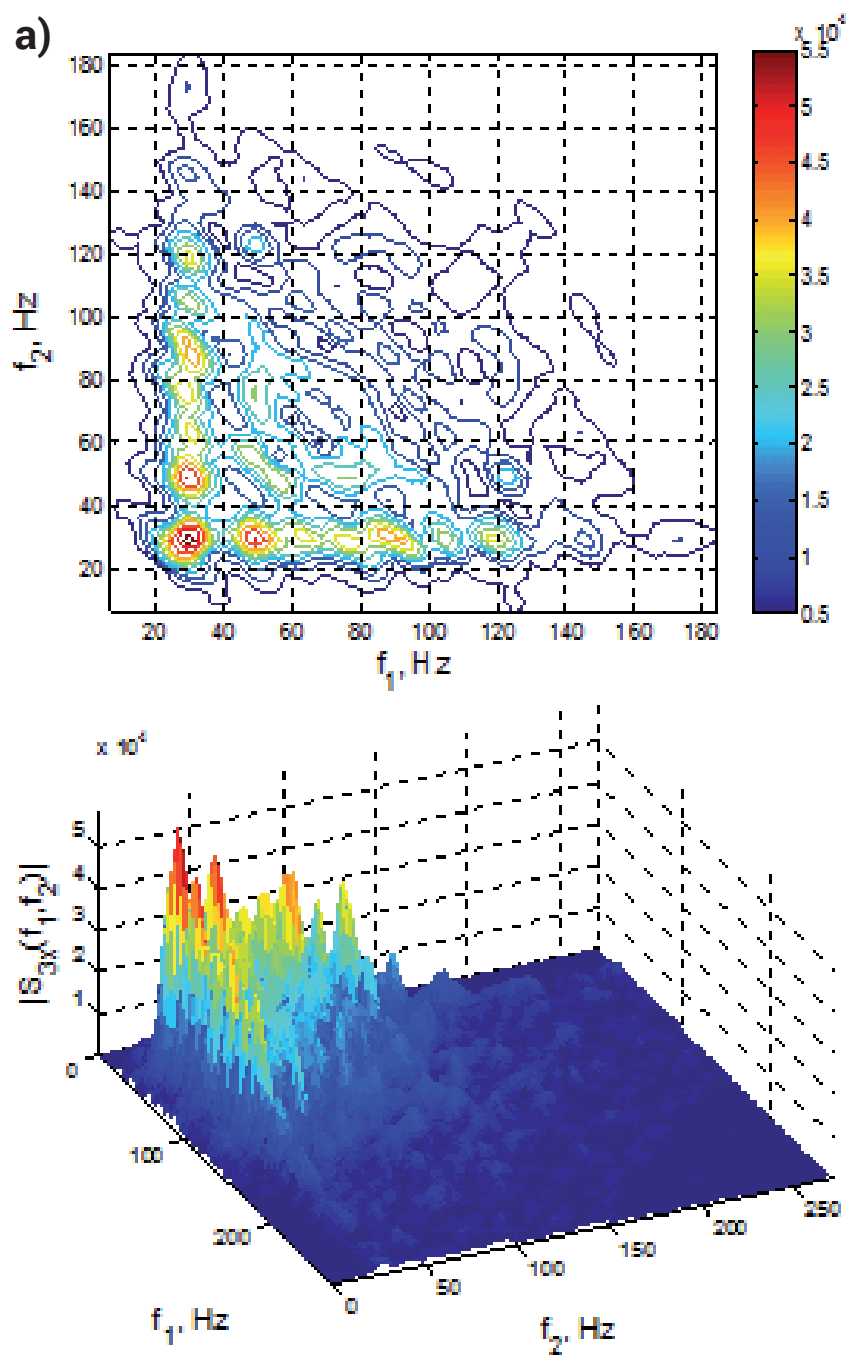

Można dostrzec, że w bispektrum sygnału zarejestrowanego dla prawidłowo realizowanego procesu spawania istnieją składowe związane z częstotliwością sieciową $(50 \mathrm{~Hz})$ i jej harmoniczne. Dominuje subharmoniczna o częstotliwości $25 \mathrm{~Hz}$. W przypadku bispektrum wyznaczonego dla sygnału zarejestrowanego w trakcie zaniku gazu osłonowego pojawiają się składowe o częstotliwości ok. $60 \mathrm{~Hz}$,
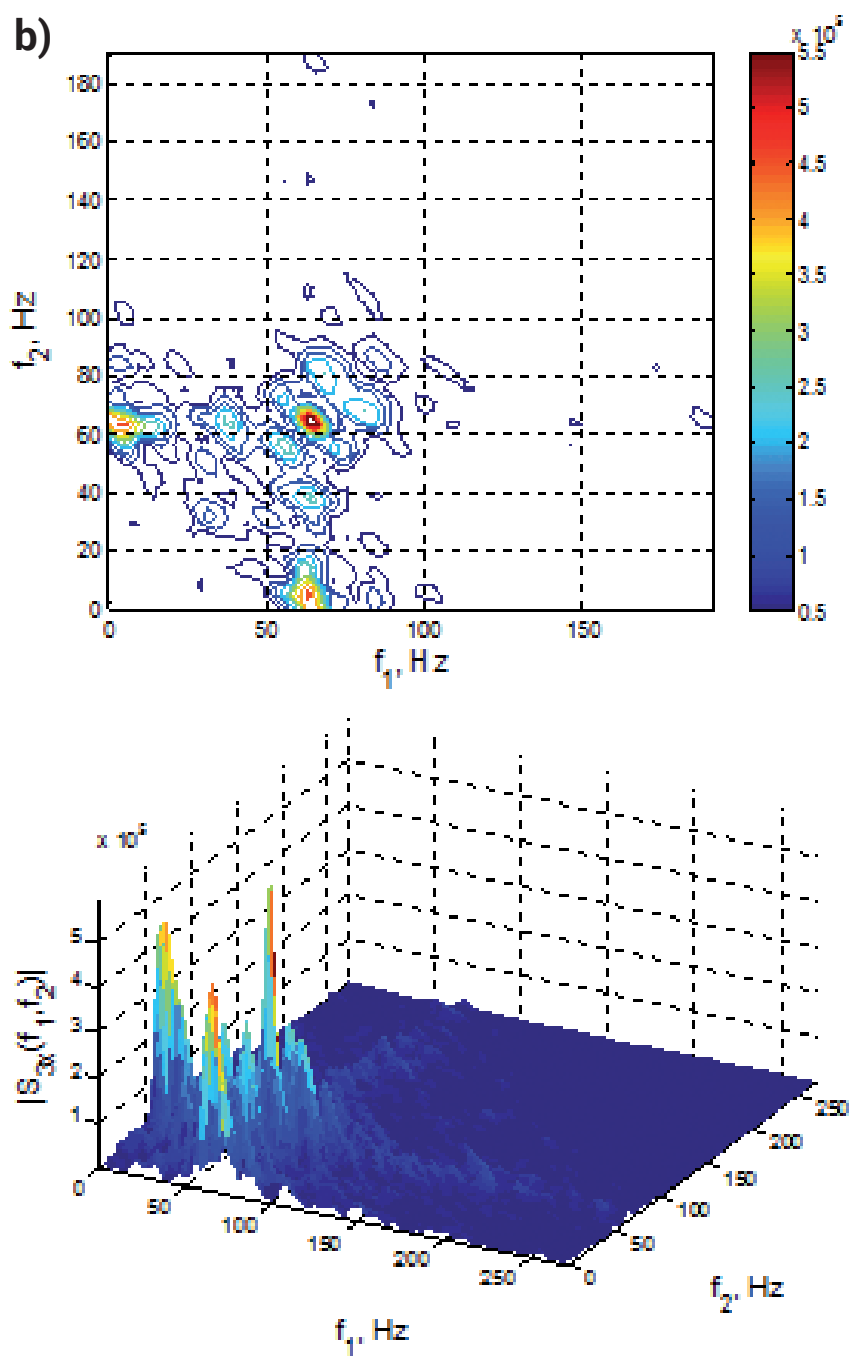

Rys. 6. Pierwsza ćwiartka bispektrum sygnału napięcia zarejestrowanego podczas spawania: a) bez zakłóceń b) z chwilowym zanikiem osłony gazowej

Fig. 6. The first quarter of Biscpectra of voltage signal acquired during welding: a) without disturbances b) with the temporary loss of shielding gas flow 
natomiast liczba składowych harmonicznych jest zdecydowanie niższa. Świadczy to o całkiem odmiennym charakterze sygnału z dominującym szumem o rozkładzie normalnym, dla którego widma wyższych rzędów przyjmują wartości zerowe.

Bazując na analizie bispektrum dla dwóch różnych stanów, postanowiono podzielić sygnał spawania na szereg krótkich podrealizacji o długości 0,128 s i dla każdego fragmentu przeprowadzić analizę bispektralną, a następnie wyznaczyć parametr S zgodnie ze wzorem (9) (por. rozdz. 2). Taka operacja pozwoliła na wyznaczenie nowego sygnału parametrycznego, którego przebieg zaprezentowano na rysunku 7 . W otrzymanym sygnale parametrycznym wyraźnie można dostrzec obszary, w których proces spawania odbywał się w warunkach nieprawidłowych. Dalsze przetwarzanie otrzymanego sygnału parametrycznego oraz przyjęcie odpowiednich wartości progowych pozwoli na wygenerowanie sygnału diagnostycznego pozwalającego sygnalizować nieprawidłowość w procesie w tym przypadku będzie to zanik gazu osłonowego. Generowanie sygnału parametrycznego wymaga określenia szerokości segmentów czasowych, dla których będzie wyznaczane

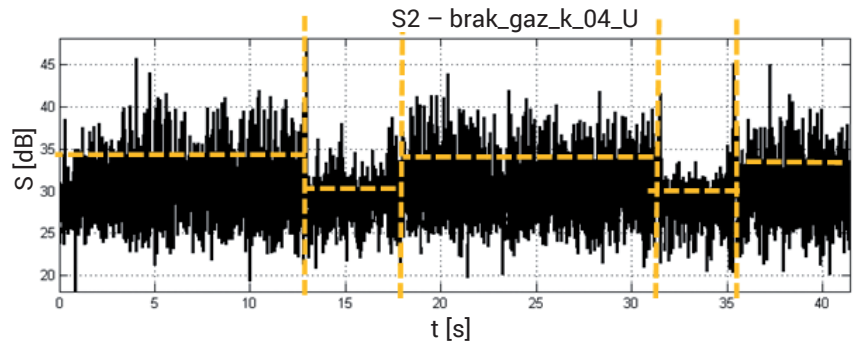

Rys. 7. Sygnał parametryczny otrzymany na podstawie sumy kwadratów składowych bispektrum wyznaczanego dla segmentów sygnału napięcia spawania

Fig. 7. Parametric signal obtained on the basis of sum of squares of bispectral components estimated for segments of signal of welding voltage

widmo wyższego rzędu. Zastosowana w badaniach szerokość segmentu była efektem wstępnych badań. W trakcie analizy pozostałych sygnałów zarejestrowanych w trakcie eksperymentu zaobserwowano, że szerokość segmentów jest różna dla potrzeb detekcji różnych nieprawidłowości, przy zaproponowanym sposobie wyznaczania wartości sygnału parametrycznego.

\section{Podsumowanie}

Zaprezentowane w artykule wyniki zastosowania analizy widmowej wyższych rzędów stanowią fragment badań wstępnych prowadzonych przez autora. Celem badań jest ocena możliwości zastosowania statystyk i widm wyższych rzędów do diagnozowania procesu spawania. Jak pokazują uzyskane wyniki, analiza sygnałów spawania z zastosowaniem widm wyższych rzędów ma ogromny potencjał zarówno w kontekście opracowania nowych parametrów liczbowych opisujących składowe widma, jak również w zakresie detekcji i klasyfıkacji różnych anomalii pojawiających się w trakcie spawania. Zaproponowany parametr diagnostyczny S nie do końca uwzględnia specyfikę rozkładu składowych w bispektrum w zależność o istniejącej anomalii procesowej, dlatego konieczne jest poszukiwanie skuteczniejszych rozwiązań pozwalających na określenie zbioru cech relewantnych, które mogą być wyznaczane na podstawie wartości składowych widma w głównej dziedzinie częstotliwości. Innym ważnym zagadnieniem jest opracowanie odpowiednich procedur przetwarzania sygnałów parametrycznych w celu podniesienia skuteczności detekcji nieprawidłowości procesowych. Wymienione zagadnienia związane $z$ analizą widmową wyższych rzędów sygnałów procesu spawania są przedmiotem aktualnie prowadzonych badań, których wyniki będą przedmiotem kolejnych publikacji autora.

\section{Literatura}

[1] Cholewa W., Korbicz J., Moczulski W., Timofiejczuk A.: Metody analizy sygnałów, [w] Korbicz J., Kościelny J.M., Kowalczuk Z., Cholewa W. (red.): Diagnostyka Procesów. Modele, metody sztucznej inteligencji. Zastosowania, PWN, Warszawa 2002, s. 115-145.

[2] Jiluan P.: Arc Welding Control, Woodhead Publishing Ltd., 2003.

[3] Luksa K.: Monitorowanie procesów spawania. Biuletyn Instytutu Spawalnictwa, nr 5/1999.
[4] Mendel, J.M.: Tutorial on higher-order statistics (spectra) in signal processing and system theory: Theoretical results and some applications, Proc. IEEE, Vol. 79, pp. 278-305, 1991.

[5] Nikias C.L.: Petropulu A.P. Higher-Order Spectra Analysis. Englewood Clifs NJ, Prentice-Hall, 1993.

[6] Swami A., Giannakis G.B., Zhou G.: Bibliography on higher-order statistics. Signal Processing 60 (1997), pp. 65-126 